\title{
Enzymatic scouring and bleaching of cotton terry fabrics - opportunity of the improvement on some physicochemical and mechanical properties of the fabrics
}

\section{Kiro Mojsov}

To cite this article: Kiro Mojsov (2018) Enzymatic scouring and bleaching of cotton terry fabrics opportunity of the improvement on some physicochemical and mechanical properties of the fabrics, Journal of Natural Fibers, 15:5, 740-751, DOI: 10.1080/15440478.2017.1361884

To link to this article: https://doi.org/10.1080/15440478.2017.1361884

\section{Published online: 01 Sep 2017.}

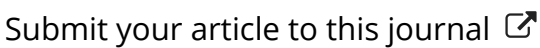

Џ Article views: 101

View Crossmark data \lceil 


\title{
Enzymatic scouring and bleaching of cotton terry fabrics - opportunity of the improvement on some physicochemical and mechanical properties of the fabrics
}

\author{
Kiro Mojsov \\ Department of Technology, Faculty of Technology, "Goce Delcev" University, Stip, The Former Yugoslav Republic Of \\ Macedonia
}

\begin{abstract}
In the present study, an attempt was made to treat cotton terry fabrics with alkaline pectinase enzyme and observe the effects on the properties including the degree of whiteness, water absorbency, pill formation, weight loss after abrasion, tenacity at maximum load, degree of polymerization (DP), and hand feeling of the fabric. The enzymatic treatment of cotton terry fabrics had a positive influence on some of their properties. The degree of damage of cotton terry fabrics after 20 washings in a domestic washing machine was determined by analyzing the tenacity at maximum load, weight loss after abrasion, fabric hand feeling, and the DP. Enzymaticscoured fabrics had a higher resistance to abrasion, a lower decrease in the DP, and a higher rating of the fabric hand feeling compared with alkaline-scoured fabrics. Enzymatic processing was accompanied by a significant lower demand of energy and water. Consequently, at these processes arises the lowest amount of effluents and the produced wastewater is biodegradable. This study attempted to introduce enzymatic scouring $(E S)$ and bleaching with peracetic acid (PAA) of the cotton terry fabrics.
\end{abstract}

\begin{abstract}
摘要
在目前的研究中, 试图用碱性果胶酶处理棉毛圈织物和观察的性质包括 白度、影响程度的吸水性, 成丸, 磨损后的重量损失, 在最大负荷强 度, 聚合度 (DP) , 和织物的手感。棉织物的酶处理对棉织物的某些性 能有积极的影响。在国内洗衣机20次通过最大负载强度测定棉毛圈织物 的损伤程度, 磨损后的重量损失, 织物手感, 和DP。酶洗织物对碱洗织 物的耐磨性较低, 织物手感较低, 对织物手感的评价较高。酶处理伴随 着对能源和水需求量的显著降低, 因此, 在这些过程中产生的废水数量 最少, 所产生的废水是可生物降解的。本研究试图引入酶精练 (ES) 和 过氧乙酸 (PAA) 漂白的棉毛圈织物。
\end{abstract}

\section{KEYWORDS}

Bleaching; cotton terry fabric; eco-friendly process; enzyme; peracetic acid; scouring

\section{关键词}

漂白; 棉毛圈织物; 环保工 艺; 酶; 过氧乙酸

冲刷

\section{Introduction}

Terry fabric is a soft, usually cotton fabric with loops that can absorb large amounts of water. Terry fabric is the most popular fabric for home textiles such as towels, and bathroom and sauna textiles. Terry fabrics have a higher water absorption property compared with other types of textile fabrics, as the end uses of terry fabrics require this. Due to their nature, terry cloth products are exposed to frequent and intensive washing. They must be resistant to water, alkalis, surfactants, and rubbing. Terry fabrics are produced by three yarn systems: weft, ground warp, and pile warp yarns. The pile can be formed on one side or on both sides of a terry fabric by pile warp yarns. Pile structure has an important effect on the structure and usage properties of 